\title{
ANALISIS TEORI BAI' TAWARRUQ DALAM MUAMALAH MALIYAH
}

\section{Asep Dadan Suganda}

IAIN Sultan Maulana Hasanuddin Banten

\begin{abstract}
Abstrak. Analisis Teori Bai' Tawarruq Dalam Muamalah Maliyah. Pesatnya perkembangan berbagai macam transaksi dalam muamalah maliyah menjadikan perdebatan dikalangan para ulama. Sebagian pihak memperbolehkan transaksi tersebut, sebagian lainnya melarangnya. Dalam bai' tawarruq misalnya, beberapa ulama membolehkan transaksinya dan sebagian lainnya melarang pelaksanaannya. Diantara ulama yang membolehkan bai' tawarruq yaitu para ulama klasik dari madzhab Hanafi, Syafi'i dan Hambali seperti Abdul Aziz bin Baz dan Muhammad ibn Shaleh al-Uthaymin. Sementara ulama yang melarang transaksi ini adalah Ibnu Taimiyah dan Abu Hanifah. Sebagian dari mazhab Maliki juga menganggap tawarruq menyerupai transaksi al-innah. Demikian pula dengan Umar bin Abdul 'Aziz, Muhammad bin al-Hasan, Ibnul Qayim, dan Ibnu Taimiyah dari mazhab Hambali juga menolak transaksi tawarruq.
\end{abstract}

Kata Kunci: bai' tawarruq, muamalah maliyah.

Abstrak. Analisis Theory of Bai' Tawarruq in Muamalah Maliyah. The rapid development of a wide range of transactions in mua'malah maliyah makes debate among the scholars. Some parties allow the transactions, and the others forbid it. In bai tawarruq for example, some scholars allow the transaction and others prohibit its execution. The scholars who allow bai tawarruq called the classical scholars of the Hanafi, Shafi'i and Hanbali like Abdul Aziz bin Baz and Muhammad ibn Salih alUthaymin. While scholars who forbid this transaction is Ibn Taymiyyah and Abu Hanifah. Most of Maliki also considers Tawarruq transaction resembles bai' al-innah. Similarly, Umar bin Abdul 'Aziz, Muhammad ibn al-Hasan, Ibn Qayim, and Ibn Taymiyyah of the Hanbali mazhab also rejected transactions of tawarruq

Key Words: bai' tawarruq, muamalah maliyah 


\section{PENDAHULUAN}

Dewasa ini di kalangan umat Islam terdapat kecenderungan untuk memperlonggar atau mepermudah hukum agama, khususnya dalam urusan muamalah. Diantara sekian alasan yang dikedepankan adalah adanya dharurah senantiasa digunakan sebagai bahan menghalalkan sesuatu yang sudah jelas diharamkan dalam syariah, seperti isu-isu yang berkaitan dengan riba misalnya.

Memang Islam memberikan keringanan (rukhsoh) dan membenarkan adanya prinsip dharuroh yang dapat digunakan apabila berada dalam keadaan terdesak hingga tidak memungkinkan lagi seseorang untuk melaksanakan tuntutan agama Islam dengan sempurna. Kaidah ushul fiqh yang terkenal dari Imam As-Sayuti yaitu:

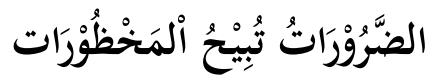

"Kondisi darurat memperbolehkan sesuatu yang semua dilarang"

Islam memberikan rukhsoh untuk memakan makanan yang diharamkan seperti daging babi, tetapi yang dibolehkan hanya sesuai kadar keperluan untuk mempertahankan hidup saja. Misalnya, jika sedang berhadapan dengan dharuroh, yaitu keadaan terdesak yang tidak memungkinkan bagi seseorang untuk mendapatkan makanan halal dan bila sesuatu yang haram (daging babi) tersebut tidak dimakan, dikhawatirkan akan menyebabkan kemusnahan atau kematian.

Hal ini berdasarkan ayat pada al-Qur'an surat al-Baqarah ayat 173 yaitu:

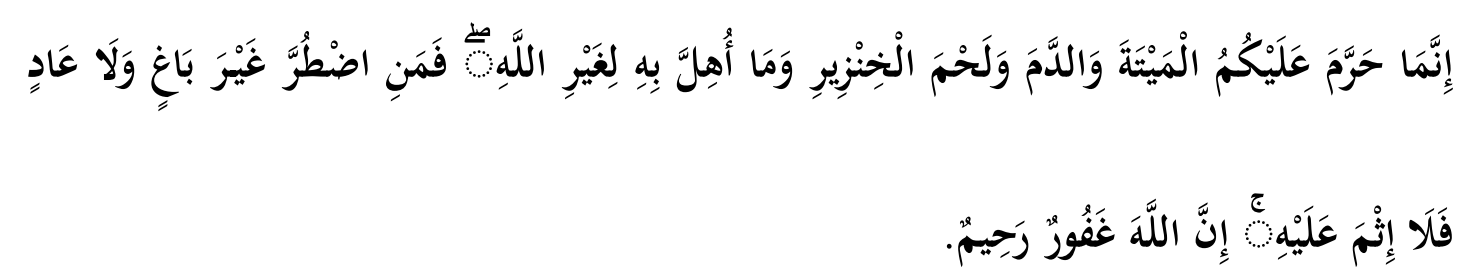

"Sesungguhnya Allah hanya mengharamkan bagimu bangkai, darah, daging babi, dan binatang (yang ketika disembelih) disebut (nama) selain Allah. Tetapi barangsiapa dalam keadaan terpaksa (memakannya) sedangkan ia tidak menginginkannya dan tidak (pula) melampaui batas, tidak ada dosa baginya. Sesungguhnya Allah Maha Pengampun lagi Maha Penyayang." 
Begitu pula dalam muamalah maliyah, bila menghadapi keadaan dharuroh seseorang dibolehkan untuk memanfaatkan rukhsoh yang diberikan oleh syariat Islam. Namun, terdapat beberapa dhawabith (aturan) yang harus terpenuhi demi tercapainya keadaan dharuroh tersebut.

Dalam kitab al-Muwafaqat, Imam Asy-Syathibi mengatakan bahwa dharuroh adalah keadaan yang terlalu mendesak, sehingga mendesak seseorang untuk tidak dapat mempertahankan lima perkara dalam syariah, yaitu agama, nyawa, akal, keturunan, dan harta.

Dari pengertian tersebut, keadaan dhoruroh berarti dimana seseorang tidak dapat lagi mempertahankan perkara-perkara yang telah disebutkan di atas, dan boleh baginya melakukan hal yang asal hukumnya haram dengan catatan sesuai kadar keperluannya untuk mempertahankan kelima perkara tersebut.

Aturan-aturan inilah yang kadangkala diselewengkan seseorang ataupun beberapa pihak untuk meluluskan berbagai kepentingan khususnya dalam muamalah maliyah-nya. Dengan mengubah ataupun melakukan modifikasi terhadap aturan yang sudah ada nash-nash-nya, justru malah ditinggalkan ketika memanfaatkan rukhsoh dalam keadaan dhoruroh. Akhirnya aturan-aturan yang awalnya harus terpenuhi sebagai syarat dhoruroh sudah tidak lagi dipenuhi.

Diantara muamalah maliyah yang cukup banyak menuai kontroversi sebagian ulama adalah bai' tawarruq. Ada beberapa ulama yang melarang jual beli tersebut, ada pula yang membolehkannya. Oleh karena itu, tulisan ini difokuskan untuk menganalisa teori bai' tawarruq dalam muamalah maliyah (A. Djazuli, 2006).

\section{PEMBAHASAN}

\section{a. Pengertian}

Tawarruq (bahasa Arab) berasal dari kata wariq, artinya karakter atau simbol dari perak. Dalam kamus Muhiith kata tawarruq berasal dari kata kertas dan koin dirham yang terbuat dari perak atau uang yang terbuat dari dirham. Jamak dari tawarruq adalah awraaq yaitu kertas yang berfungsi menggantikan uang atau uang kertas. Kata tawarruq ini digunakan untuk mengartikan mencari perak, sama dengan kata ta'allum, yang artinya mencari ilmu, yaitu belajar atau sekolah. Kemudian 
diartikan lebih luas lagi menjadi mencari uang tunai dengan berbagai cara, yaitu bisa dengan mencari perak, emas atau semacamnya (Al-Fairuzi).

Sedangkan secara istilah, Ibrahim Fadhil Dabu mengartikan tawarruq sebagai suatu kegiatan dimana ketika seorang membeli suatu komoditi secara kredit (angsuran) pada harga tertentu dan kemudian menjualnya untuk mendapatkan likuiditas (uang) kepada pihak lain (secara tunai) pada harga yang lebih rendah dari harga asalnya. Jika orang tersebut menjualnya ke pihak penjual pertama, maka hal tersebut menjadi tergolong transaksi terlarang yang disebut Bai' al-Inah (Ibrahim Fadhil).

Ahmad Ifham Sholihin dalam bukunya mengartikan tawarruq; penguatan asset yaitu jual beli asset yang dilakukan secara tangguh dengan pembeli menjual kembali asset itu secara tunai kepada pihak ketiga. Istilah tawarruq adalah sebagai berbagai cara yang ditempuh untuk mendapatkan uang tunai atau likuditas (Ahmad Ifham, 2010).

Istilah tawarruq ini di perkenalkan oleh Mazhab Hambali. Mazhab Shafi'i mengenal tawarruq dengan sebutan "zarnagah", yang artinya bertambah atau berkembang. Dalam Hukum Islam, tawarruq artinya adalah struktur yang dapat dilakukan oleh seorang mustawriq/ mutawarriq yaitu seorang yang membutuhkan likuditas. Transaksi tawarruq adalah ketika seseorang membeli sebuah produk dengan cara kredit (pembayaran dengan cicilan) dan menjualnya kembali kepada orang ketiga yang bukan pemilik pertama produk tersebut dengan cara tunai, dengan harga yang lebih murah (Anwar, 1996).

Ascarya (2007) mengatakan bahwa tawarruq adalah bentuk akad jual beli yang melibatkan tiga pihak, ketika pemilik barang menjual barangnya kepada pembeli pertama dengan harga dan pembayaran tunda, dan kemudian pembeli pertama menjual kembali barang tersebut kepada pembeli akhir dengan harga dan pembayaran tunai. Harga tunda lebih tinggi daripada harga tunai, sehingga pembeli pertama seperti mendapatkan pinjaman uang dengan pembayaran tunda.

\section{b. Pembagian Mekanisme Tawarruq}

Tawarruq dibagi menjadi tiga mekanisme yaitu: 
1. Seseorang yang membutuhkan uang tunai (likuiditas), membeli barang dari pihak I dengan cara cicilan (credit) dan tempo waktu kredit telah ditentukan. Kemudian ia menjual kembali barang tersebut kepada pihak III tanpa sepengetahuan pihak I dengan harga lebih rendah secara tunai (cash).

2. Seseorang (mutawarriq) yang membutuhkan uang tunai, kemudian berusaha meminjam, tapi orang yang dituju tidak ingin meminjamkan uang tunai melainkan orang tersebut menawarkan barang dagangannya untuk dibeli oleh mutawarriq secara kredit. Kemudian mutawarriq dapat menjual kembali barang tersebut kepada orang lain dengan harga lebih rendah atau lebih tinggi secara tunai.

3. Seseorang yang membutuhkan uang tunai, kemudian berusaha meminjam tapi orang yang dituju tidak ingin meminjamkan uang tunai, dia menawarkan barang dagangannya dengan harga tinggi oleh orang yang membutuhkan likuiditas (secara kredit). Kemudian barang tersebut dapat dia jual kembali dengan harga rendah ataupun lebih tinggi secara tunai. (khiyar yang diberikan penjual adalah khiyar paksa kepada mutawarriq yang sangat membutuhkan dana tunai).

Berikut adalah penjelasan keadaan dan perbedaan dari ketiga mekanisme tawarruq:

\begin{tabular}{|c|c|l|}
\hline No. & \multicolumn{1}{|c|}{ Keadaan } & \multicolumn{1}{|c|}{ Perbedaan } \\
\hline 1. & Mekanisme Tawarruq 1 & $\begin{array}{l}\text { Penjual tidak mengetahui keadaan } \\
\text { dan tujuan dari si pembeli }\end{array}$ \\
\hline 2. & Mekanisme Tawarruq 2 & $\begin{array}{l}\text { Penjual mengetahui keadaan dan } \\
\text { tujuan si pembeli, namun ia tidak } \\
\text { peduli }\end{array}$ \\
\hline 3. & Mekanisme Tawarruq 3 & $\begin{array}{l}\text { Penjual mengetahui keadaan dan } \\
\text { tujuan si pembeli, namun } \\
\text { memaksa untuk membeli kepada si } \\
\text { pembeli demi mencari keuntungan } \\
\text { sebesar-besarnya }\end{array}$ \\
\hline
\end{tabular}

Sumber: Nadratuzzaman, 2012. 
Pengertian dan mekanisme tawarruq sebagaimana diuraikan diatas merupakan pengertian dan mekanisme tawarruq murni yang sering disebut sebagai tawarruq fiqih atau clasical tawarruq. Sedangkan tawarruq yang diterapkan oleh perbankan syariah disebut tawarruq munazam atau organized tawarruq.

Berikut adalah bagan tawarruq secara umum:

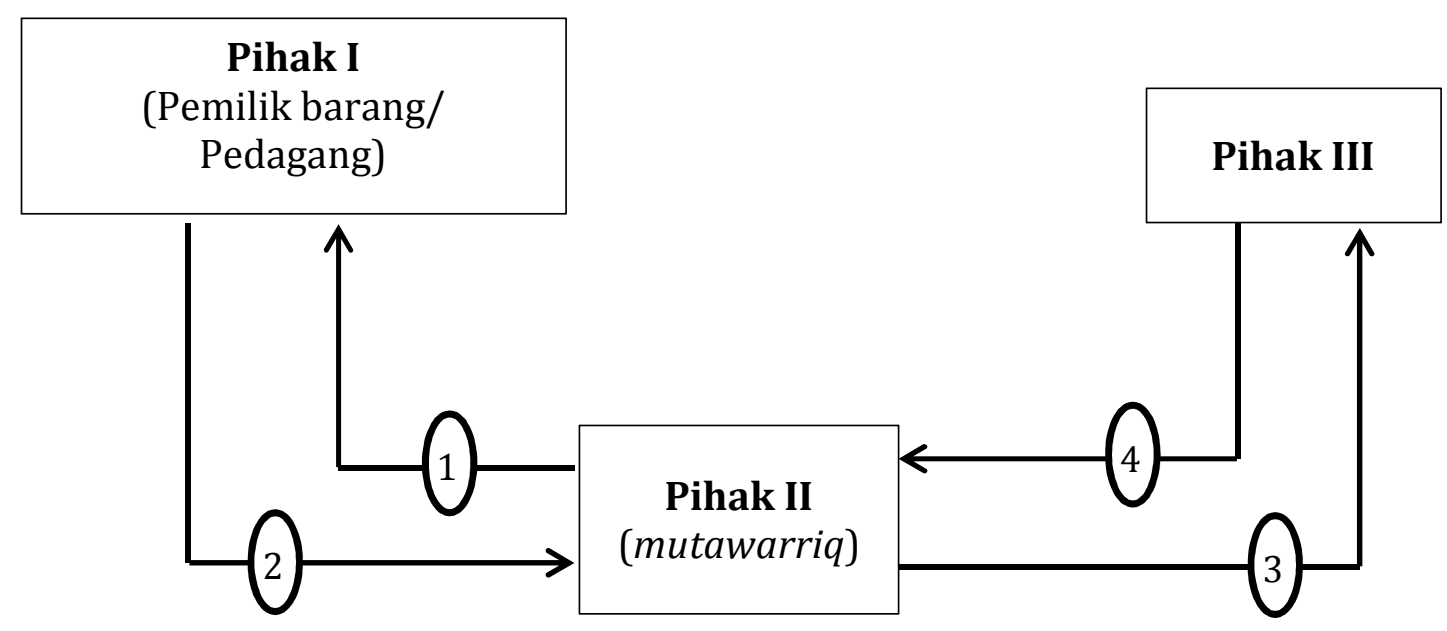

Keterangan bagan:

1. Seseorang yang memerlukan uang tunai (mutawarriq) mendatangi pihak I untuk meminjam uang/ membeli barang dagangannya

2. Pihak I (Pemilik barang/ pedagang) menjual barangnya kepada mutawarriq secara kredit (bayar tunda)

3. Mutawarriq menjual kembali barang yang diperoleh dari pihak I kepada pihak ke III

4. Pihak ke III membeli barang dari mutawarriq secara pembayaran tunai. (Ascarya, 2007 dan dimodifikasi kembali oleh penulis)

\section{c. Pendapat Para Ulama}

Terjadi perbedaan pendapat dalam persoalan tawarruq ini dikalangan para ulama, ada yang membolehkan dan ada pula yang melarangnya. Masing-masing memiliki dalil dan hujjah yang memperkuat pendapatnya. Berikut ini beberapa pendapat para ulama berkenaan dengan persoalan tawarruq, yaitu: 


\section{Pendapat yang Membolehkan}

Para ulama klasik dari madzhab Hanafi, Syafi'i dan Hambali memberikan pandangan bahwa transaksi tawarruq sebagai transaksi yang sah/ legal, diantaranya Abdul Aziz bin Baz dan Muhammad ibn Shaleh al-Uthaymin.

Kebolehan akad tawarruq diatur dalam Fatawa Lajnah Ad-Daimah No. 19297 Jilid 13 Halaman 161, keputusan Divisi Fikih Rabithah Alam Islami yang mana juga diperkuat oleh Dewan Akademi Fikih OKI (Organisasi Kerjasama Islam) dalam fatwanya No.179 yaitu mengharamkan jenis tawarruq munazzam. Jenis tawarruq yang diperbolehkan adalah tawarruq fardi atau tawarruq fiqhi (tawarruq haqiqi) yang mana sesuai dengan Fatwa DSN-MUI No. 82/DSNMUI/VIII/2011 dan diaplikasikan dalam Perdagangan Komoditi Syariah di Bursa Berjangka Jakarta Indonesia.

Ulama yang membolehkan dan menganggap sah transaksi tawarruq berlandaskan kepada ayat-ayat al-Qur'an dan qaidah fiqhiyah, yaitu: "Semua transaksi jual beli halal, kecuali transaksi jual beli yang telah ada dalil pengharamannya oleh al-Qur'an dan Sunnah."

Selain itu terdapat hadist Bukhari-Muslim yang dijadikan sandaran para ulama untuk membolehkan tawarruq, yaitu: ketika seorang petani dari Khaibar datang kepada Rasulullah SAW dengan membawa kurma kualitas terbaik. Rasulullah SAW bertanya kepadanya: “Apa semua kurma Khaibar sangat bagus kualitasnya?" petani menjawab: "Tidak, saya telah menukar dua kilo gram kurma berkualitas rendah dengan satu kilogram kurma berkualitas unggulan." Mendengar jawaban petani tersebut, Rasulullah SAW melarangnya dan menyarankan untuk menjual semua kurma berkualitas rendahnya secara tunai untuk mendapatkan uang, kemudian membeli kurma dengan kualitas unggulan.

\section{Pendapat yang Melarang}

Diantara yang tidak setuju terhadap penjualan barang dengan harga yang lebih tinggi dari harga pasar apabila dilakukan oleh seseorang yang mengambil keuntungan pinjaman dengan cara yang masuk kategori riba adala para ulama dari mazhab Maliki. 
Sebagian dari mazhab Maliki ini menganggap tawarruq menyerupai transaksi al-innah. Demikian pula dengan Umar bin Abdul 'Aziz, Muhammad bin al-Hasan, Ibnul Qayim, dan Ibnu Taimiyah dari mazhab Hambali juga menolak transaksi tawarruq.

Ulama yang menolak transaksi tawarruq berargumentasi bahwa adanya niatan untuk mendapatkan uang dengan cara yang sama seperti menjual uang demi mendapatkan uang lebih, sementara barang tersebut digunakan untuk media transaksi bukan berdasarkan niat kepemilikan barang tersebut. Maka terlihat jelas bahwa dalam transaksi ini ada unsur manipulasi untuk mendapatkan uang tunai dengan rekayasa dua macam pembayaran yang berbeda untuk menghindari riba.

Apabila hasil akhir dari sebuah transaksi adalah untuk mendapatkan uang, maka praktik transaksi ini sama halnya untuk mendapatkan riba. Ini berdasarkan kesepakatan para ulama bahwa hasil akhir dari transaksi sangatlah penting dan menentukan sah atau tidaknya sebuah transaksi tersebut, dengan demikian tawarruq sama halnya dengan 'innah yang telah dilarang transaksinya oleh Rasulullah SAW karena memiliki tujuan yang sama yaitu mendapatkan uang tunai dan bukan kepemilikan barang yang telah dibelinya.

Ibnu 'Abbas ra. Berkata: "Hal demikian merupakan transaksi uang terhadap uang dengan meletakkan kain sutra di tengah-tengah transaksi."

\section{d. Pendapat Pakar Ekonomi Syariah dan DSN-MUI}

Karim mengungkapkan bahwa pelaksanaan suatu akad haruslah disertai kesiapan dan kesigapan masyarakat dalam mengimplementasikannya. Pengesahan pada mekanisme akad harus disesuaikan dengan ketepatan waktu, yaitu ketika masyarakat sudah memahami, menerima dan mengamalkan fatwa suatu transaksi (Karim, 2007).

Diharapkan dengan adanya ketetapan ini akan terlaksana sebuah mekanisme akad yang sesuai dengan maqasid syariah. Kesiapan masyarakat dalam menerima dan mengamalkan sebuah teori adalah hal yang utama, karena meskipun transaksi tersebut secara teori halal, tetapi jika masyarakat belum siap menerima dan 
melaksanakan teori tersebut dampaknya bisa mendatangkan kemudharatan dan menghilangkan tujuan awal syariat agama Islam (maqasid syariah).

DSN-MUI sebagai lembaga pengambil keputusan mengenai produk-produk perbankan dan transaksi syariah di Indonesia memberikan pendapat mengenai praktik tawarruq. Hingga saat ini, tawarruq di Indonesia masih dikaji karena terdapat berbagai aspek-aspek yang memerlukan peninjauan lebih mendalam lagi, dari datadata yang diperoleh dari lapangan sampai kepada teori-teori para ulama terdahulu antara khilafiyah dan mashlahah yang terkandung dalam transaksi tawarruq pada muamalah maliyah. Hingga saat ini tawarruq belum dibolehkan atas dasar sadduzzarai' dengan tujuan menutup pintu yang menuju kepada zari'ah. Tetapi, apabila zari'ah tersebut dapat dihilangkan maka praktik tawarruq akan berubah menjadi boleh atau sah dipraktikkan dalam muamalah maliyah.

Berikut ini beberapa pendapat ulama tentang tawarruq:

\begin{tabular}{|c|c|c|c|}
\hline No. & Ulama & Pendapat & Alasan \\
\hline 1. & Jumhur Ulama & Boleh & Diartikan sebagai jual beli \\
\hline 2. & Bin Baz & Boleh & $\begin{array}{l}\text { Berbeda dengan bai' 'innah dan } \\
\text { memudahkan serta memungkinkan } \\
\text { masyarakat memenuhi kebutuhannya }\end{array}$ \\
\hline 3. & Ibnu Uthaimeen & Boleh & $\begin{array}{l}\text { Merupakan salah satu jenis pinjaman yang } \\
\text { diperbolehkan dengan membeli suatu butir } \\
\text { untuk suatu pembayaran angsuran, } \\
\text { kemudian menjualnya kepada orang lain }\end{array}$ \\
\hline 4. & Ibnu Taimiyah & Dilarang & $\begin{array}{l}\text { Sama dengan bai' 'innah. Tetapi dapat } \\
\text { menjadi boleh apabila memenuhi syarat } \\
\text { berikut: } \\
\text { - Seseorang sedang dalam kekurangan } \\
\text { uang. Jika tidak kekurangan uang maka } \\
\text { tidak diizinkan } \\
\text { - Ketika kontrak tidak meliputi format } \\
\text { riba } \\
\text { - Peminjam tidak menjualnya sampai ia }\end{array}$ \\
\hline
\end{tabular}




\begin{tabular}{|c|c|c|c|}
\hline & & & $\begin{array}{l}\text { telah menempati tentangnya dan } \\
\text { memindahkan kepemilikannya. Karena } \\
\text { Rasulullah SAW melarang penjualan } \\
\text { sesuatu butir sebelum pedagang pindah } \\
\text { gerak }\end{array}$ \\
\hline 5. & Abu Hanifah & Dilarang & $\begin{array}{l}\text { Boleh, jika melibatkan pihak ketiga (bukan } \\
\text { sale and buy back) }\end{array}$ \\
\hline
\end{tabular}

Sumber: Ascarya (2007) dan dimodifikasi oleh penulis

\section{e. Analisis Teori Bai' Tawarruq Dalam Muamalah Maliyah}

Dari berbagai argumentasi mengenai tawarruq yang telah dikemukakan di atas, beberapa ulama ada yang membolehkan dan ada pula yang melarangnya. Jumhur ulama mengizinkan transaksi tawarruq dalam muamalah maliyah sebatas tidak ada indikasi-indikasi yang mengarah kepada praktik riba.

Kondisi yang perlu terus diawasi dalam transaksi tawarruq harus berdasarkan kepada skala kebutuhan yang mendesak (dhoruroh), bukan yang berdasarkan hanya keinginan semata, sehingga pemberian regulasi dalam hal tawarruq benar-benar sesuai dengan syariat Islam.

Ketika dihadapkan kepada permasalahan mengenai kebutuhan seseorang untuk mendapatkan uang tunai (likuiditas) dengan menggunakan mekanisme tawarruq haruslah benar-benar berdasarkan kebutuhan orang tersebut, bukan untuk kebutuhan orang lain. Sehingga, ulama ada yang berpendapat bahwa bai' tawarruq diperbolehkan apabila tidak ada cara lain lagi untuk memperoleh uang tunai.

Agar tawarruq dapat diterima oleh berbagai pihak, para ulama memberikan syarat dalam pembuatan regulasinya, sehingga akan diperoleh kepastian sahnya transaksi jual beli tersebut. Syarat-syaratnya adalah:

1. Penjual yang menjual barang kepada mutawarriq harus memiliki barang itu pada saat berlangsungnya transaksi jual beli.

2. Penjualan yang kedua harus kepada pihak ke tiga, bukan kepada pihak pertama.

Rasulullah SAW bersabda: "Janganlah kamu menjual barang yang tidak kamu miliki". Maksudnya, tidak sah akad jual beli apabila penjual tidak memiliki barang 
yang akan dijual kepada pembeli. Hal ini telah menjadi ketentuan dalam transaksi jual beli bahwa kepemilikan terhadap barang adalah menjadi syarat sahnya transaksi tersebut, seperti yang telah diatur dalam syariah.

Diantara struktur tawarruq yang sudah diadopsi oleh Lembaga Keuangan Syariah dikenal dengan tawarruq munazam atau regulated tawarruq dikenal juga dengan organized tawarruq.

Tawarruq munazam terjadi apabila seorang nasabah membeli suatu barang dari bank dengan prinsip murabahah, kemudian pembayarannya dilakukan dengan harga tangguh (cicilan) dengan tempo yang telah disetujui kedua belah pihak. Setelah barang tersebut pindah tangan, nasabah menunjuk bank sebagai wakilnya untuk menjual kembali barang tersebut kepada nasabah yang lain dengan harga yang lebih rendah tetapi dibayarnya secara tunai.

Dalam tatanan muamalah maliyah level internasional, transaksi tawarruq munazam juga dapat dilaksanakan misalnya sebuah bank syariah membeli suatu barang dari pasar internasional secara tunai, kemudian menjual kembali kepada nasabahnya menggunakan akad murabahah dengan harga lebih tinggi. Lalu bank menjual kembali barang tersebut mewakili nasabahnya secara akad wakalah kepada pihak ketiga. Dana yang dibayarkan kepada bank akan diserahkan kepada nasabah atau dimasukkan ke dalam rekening nasabah, yang akan membayar transaksi murabahah secara cicilan dengan harga lebih tinggi sesuai dengan perjanjian awal. Pada mekanisme ini melibatkan broker pasar komoditas internasional, yang mendapatkan komisi untuk jasanya.

Prosedur tawarruq munazam dapat dirincikan poin-poin transaksinya sebagai berikut:

1. Seorang nasabah yang membutuhkan dana mendatangi bank syariah, membuat perjanjian dengan bank tersebut untuk membeli komoditas dari bank setelah bank membelinya dari broker.

2. Bank syariah membeli komoditas

3. Bank syariah menjual kembali komoditas tersebut kepada nasabah dengan harga tangguh (cicilan)

4. Nasabah akan menunjuk bank sebagai wakilnya untuk menjual kembali komoditas tersebut kepada pihak ketiga dengan bayaran tunai 
5. Bank syariah menjual komoditas tersebut kepada pihak ketiga (nasabah lain atau broker lain) dibayar secara tunai

6. Uang tunai hasil penjualan disetorkan ke rekening nasabah yang telah menunjuk bank syariah tersebut sebagai wakilnya

7. Setelah nasabah mendapatkan dana yang dibutuhkannya, nasabah memiliki kewajiban membayar cicilan kepada bank atas pembelian komoditas sesuai perjanjian diawal atas pembelian komoditas pada transaksi poin ke-3 di atas.

Biasanya untuk menghindari tingkat kerumitan dalam transaksi murabahah, beberapa bank meniadakan beberapa prosedur transaksi. Misalnya, prinsip wakalah dari nasabah dalam pembelian barang dari pihak luar, biasanya bank sudah memiliki rekanan show room atau dealer untuk transaksi kendaraan bermotor, toko elektronik sebagai penyedia barang-barang elektronik dan sebagainya agar proses jual beli secara murabahah-nya lebih mudah.

Maka terdapat beberapa perbedaan antara akad tawarruq fiqhi dan tawarruq munazam, yaitu:

\begin{tabular}{|c|l|l|}
\hline No. & \multicolumn{1}{|c|}{ Tawarruq Fiqhi } & \multicolumn{1}{|c|}{ Tawarruq Munazam } \\
\hline 1. & Dilakukan oleh tiga pihak & Dilakukan oleh empat pihak \\
\hline 2. & $\begin{array}{l}\text { Tidak ada perjanjian untuk } \\
\text { membeli }\end{array}$ & $\begin{array}{l}\text { Ada perjanjian diawal untuk membeli } \\
\text { barang (komoditas) }\end{array}$ \\
\hline 3. & Hanya ada dua dasar jual beli & $\begin{array}{l}\text { Tidak ada perjanjian untuk membeli } \\
\text { dari nasabah (mutawarriq) }\end{array}$ \\
\hline 4. & Tidak ada MoU & Nsabah menjual sendiri komoditas \\
\hline 6. & $\begin{array}{l}\text { Pelibatkan perjanjian bersama (MoU) } \\
\text { fisik terjadi, setiap kali transaksi }\end{array}$ & $\begin{array}{l}\text { nang harus sesuai dengan prosedur } \\
\text { kepada pihak lain }\end{array}$ \\
\hline
\end{tabular}

Sumber: Nadratuzzaman (2012) dan dimodifikasi oleh penulis 


\section{KESIMPULAN}

Bai' tawarruq adalah bentuk akad jual beli yang melibatkan beberapa pihak, ketika pemilik barang menjual barangnya kepada pembeli pertama dengan cara pembayaran tunda (kredit), kemudian pembeli pertama menjual kembali barang tersebut kepada pembeli lain dengan tunai.

Pada asalnya, bai' tawarruq terjadi ketika seseorang dalam keadaan dhoruroh memerlukan uang tunai (likuiditas), kemudian membeli barang dari pihak I dengan cara cicilan (credit) dan tempo waktu kredit telah ditentukan. Kemudian ia menjual kembali barang tersebut kepada pihak III dengan harga lebih rendah secara tunai (cash).

Dalam muamalah maliyah, bila menghadapi keadaan dhoruroh seseorang dibolehkan untuk memanfaatkan rukhsoh yang diberikan oleh syariat Islam. Namun, terdapat beberapa dhawabith (aturan) yang harus terpenuhi demi tercapainya keadaan dharuroh tersebut.

Inilah yang menjadikan munculnya perdebatan oleh beberapa kalangan ulama mengenai boleh atau tidaknya bai tawarruq. Sejumlah ulama berpendapat bahwa bai' tawarruq dibolehkan dan telah diperkenalkan Islam sebagai solusi untuk memenuhi kebutuhan akan likuiditas. Namun, sebagian lainnya berpandangan bahwa tawarruq adalah sebuah kegiatan muamalah maliyah yang dibuat-buat untuk menutupi unsur ribanya dan mengakali keadaan dhorurah dalam kebutuhan akan likuiditas, padahal esensi dari transaksi ini masih tergolong kepada kegiatan ribawi.

Diantara ulama yang membolehkan bai' tawarruq adalah para ulama klasik dari madzhab Hanafi, Syafi'i dan Hambali diantaranya Abdul Aziz bin Baz dan Muhammad ibn Shaleh al-Uthaymin. Sementara ulama yang melarang transaksi ini adalah Ibnu Taimiyah dan Abu Hanifah. Sebagian dari mazhab Maliki juga menganggap tawarruq menyerupai transaksi al-innah. Demikian pula dengan Umar bin Abdul 'Aziz, Muhammad bin al-Hasan, Ibnul Qayim, dan Ibnu Taimiyah dari mazhab Hambali juga menolak transaksi tawarruq. 


\section{PUSTAKA ACUAN}

A. Djazuli, 2006. Kaidah-Kaidah Fikih: Kaidah-Kaidah Hukum Islam, cet. Ke-3 Jakarta: Prenada Media Group.

Adiwarman karim, 2007. Bank Islam, Analisis Fiqih dan Keuangan. Jakarta: Raja Grafindo Persada.

Ahmad Ifham Sholihin, 2010. Buku Pintar Ekonomi Syariah. Jakarta: PT Gramedia Pustaka Utama.

Al-Bukhari, 2000. Shahih al-Bukhari. Riyad: Darussalam Publishing.

Ascarya, 2007. Akad \& Produk Bank Syariah. Jakarta: PT. Raja Grafindo Persada.

Ibrhim Fadhil Dabu, TT. Tawarruq, It's Reality and Types

M. N. Hosen, 2008. Materi Dakwah Ekonomi Syariah. Jakarta: Pusat Komunikasi Ekonomi Syariah.

Moch. Anwar, 1996. 100 Masail Fiqhiyah. Kudus: Menara Kudus.

Muhamad Nadratuzzaman, 2012. Produk Keuangan Islam di Indonesia dan Malaysia. Jakarta: PT Gramedia Pustaka Utama.

Mujiduddin M. bin Ya'cub al Fairuzi. Qamus al Muhith 1 - 4, Dar al Jiil.

Safi'i Antonio, 1999. Bank Syariah bagi Bankir dan Praktisi Keuangan. Jakarta: Tazkia Institute. 2001. Bank Syariah dari Teori ke Praktek. Jakarta: Gema Insani Press. 